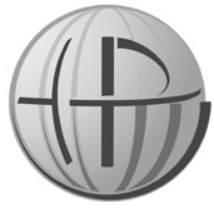

Horyzonty Polityki 2019, Vol. 10, No 33

\section{Krystian Bartosz}

http://orcid.org/0000-0002-0571-7700 Wyższa Szkoła Prawa i Administracji w Rzeszowie kry.bar1994@gmail.com DOI: 10.35765/HP.2019.1033.05

\title{
Służba Ochrony Państwa a Biuro Ochrony Rządu w kontekście zmian ustawowych
}

\section{Streszczenie}

CEL NAUKOWY: Artykuł stawia sobie za cel dogłębną analizę motywów przekształcenia Biura Ochrony Rządu w Służbę Ochrony Państwa.

PROBLEM I METODY BADAWCZE: Autor, analizując teksty źródłowe oraz wykorzystując metodę sondażu diagnostycznego, prezentuje główne przyczyny zmiany formacji strzegących bezpieczeństwa najważniejszych osób w Polsce.

PROCES WYWODU: Autor po chronologicznym omówieniu historii ochrony najważniejszych osób w państwie skupia się na wskazaniu głównych przyczyn likwidacji Biura Ochrony Rządu. Dokonuje analizy porównawczej z nowo powołaną do życia Służbą Ochrony Państwa oraz wyznacza pożądane kierunki jej rozwoju.

WYNIKI ANALIZY NAUKOWEJ: Podając w wątpliwość wskazane w tekstach źródłowych przyczyny likwidacji Biura Ochrony Rządu, autor zwrócił uwagę na konkretne rozwiązania mogące skutecznie zahamować proces destrukcji tej instytucji. Przeprowadzona analiza porównawcza pozwoliła realnie wykazać różnice w działalności obydwu formacji. Dzięki wykorzystaniu metody sondażu diagnostycznego, przeprowadzonego wyłącznie na funkcjonariuszach Biura Ochrony Rządu oraz Służby Ochrony Państwa, uzyskano jednoznaczne wnioski co do całości procesu przeistoczenia. 
WNIOSKI, INNOWACJE, REKOMENDACJE: Przeprowadzenie dogłębnej analizy tekstów źródłowych pozwoliło na jednoznaczne potwierdzenie tezy, iż reforma w zakresie ochrony najważniejszych osób w Polsce była nieunikniona i potrzebna. Jej forma, generująca niebotyczne koszty związane z zamknięciem Biura Ochrony Rządu i powołaniem w jej miejsce Służby Ochrony Państwa, wydaje się jednak bezzasadna, biorąc pod uwagę możliwość przeprowadzenia gruntownej reorganizacji działania i struktur BOR.

\section{SŁOWA KLUCzowe:}

Biuro Ochrony Rządu, Służba Ochrony Państwa, ochrona, bezpieczeństwo, służby, prawo

\section{Abstract}

\section{STATE PROTECTION SERVICE AND GOVERNMENT PROTECTION BUREAU IN THE SPECIFIC CONTEXT OF LEGISLATIVE AMENDMENT}

RESEARCH OBJECTIVE: The aim of the article is to provide a thorough analysis of the motives behind replacing Government Protection Bureau with State Protection Service.

THE RESEARCH PROBLEM AND METHODS: Through the analysis of the source texts and the usage of diagnostic survey method, the author presents the main reasons of the changes in formations responsible for the safety of the most important persons in the State.

THE PROCESS OF ARGUMENTATION: The author presents the history of the most important persons in the State security system following the chronological order. The focus is on the main reasons of the Government Protection Bureau liquidation. The comparative analysis of the Government Protection Bureau and State Protection Service is provided, the author also pointed the desirable course of future development.

RESEARCH RESULTS: The author casts doubt on the reasons of the Government Protection Bureau liquidation, which were given in the source texts. The attention is directed to a specific solutions to stop the destruction process. The conducted comparative analysis led to the identification of the number of differences between both formations. Due to the diagnostic survey method that was conducted exclusively on Government Protection Bureau and State Protection Service officers, clear conclusions on the transition process were obtained. 
CONCLUSIONS, RECOMMENDATIONS, AND INNOVATIONS: The carried out thorough analysis of the source texts confirmed the thesis that the security formation reform was inevitable and justifiable. Nevertheless, taking into consideration the possibility of the reorganization of the activities and structures of Government Protection Bureau, the new formation that due to the Government Protection Bureau closure, generates exorbitant costs seems to be illegitimate.

\section{KeYwORDS:}

State Protection Service, Government Protection Bureau, protection, security, law

\section{WSTĘP}

1 lutego 2018 r. stał się symboliczną datą zmiany, jaka nastąpiła $\mathrm{w}$ Polsce $\mathrm{w}$ zakresie ochrony najważniejszych osób $\mathrm{w}$ państwie. To wtedy swoją działalność zakończyło Biuro Ochrony Rządu (BOR), a w jego miejsce utworzono Służbę Ochrony Państwa (SOP). Powołane do życia na mocy zarządzenia nr 00238/56 ministra z 29 listopada 1956 r. Biuro Ochrony Rządu przez 65 lata wykonywało zadania z zakresu ochrony obiektów, urządzeń, a przede wszystkich najważniejszych osób w państwie (Zarządzenie, 1956). Co zatem skłoniło Radę Ministrów RP do tak dużej zmiany? Według oficjalnych doniesień, BOR nie spełniało już należycie swojej funkcji, było formacją niedofinansowana, słabo wyszkoloną i z dużymi problemami kadrowymi. Borykało się również z problemami wizerunkowymi. Nowa formacja ma odciąć się od problemów swojej poprzedniczki i dać świeże otwarcie w dziedzinie ochrony VIP-ów w Polsce.

\section{PRZYCZYNY LIKWIDACJI BOR}

Biuro Ochrony Rządu przez cały okres swojej działalności miewało lepsze i gorsze momenty. Zastanawia fakt, co skłoniło Radę Ministrów RP do tak drastycznej zmiany, jak zamknięcie jednej z najbardziej elitarnych służb w kraju nad Wisłą. Czy zaniedbania wykazane przez Ministra Spraw Wewnętrznych i Administracji w 2016 r. 
wymagały zmiany ustawy, czy może wystarczający okazałby się program naprawczy i modernizacyjny?

Według raportu pokontrolnego Najwyższej Izby Kontroli, przeprowadzonego przez Departament Obrony Narodowej i Bezpieczeństwa Wewnętrznego za okres od stycznia 2002 do grudnia 2004 r., dotyczącego realizacji ustawowych zadań przez BOR, formacja swoje zadania wypełniała w sposób prawidłowy. NIK nie stwierdziła uchybień $\mathrm{w}$ dziedzinie ochrony osób oraz zadań z zakresie profilaktyki ochronnej. Jedyne nieprawidłowości dotyczyły niskiej sprawności urządzeń technicznych oraz zakresu zamówień publicznych (Najwyższa Izba Kontroli, 2006). Co zatem zmieniło się przez kilka następnych lat, że BOR musiało zostać zamknięte?

Były już Minister SWiA odpowiedzialny za przekształcenie BOR w SOP, Mariusz Błaszczak, na antenie Polskiego Radia stwierdził, że odchodząca służba była niedofinansowana i źle przeszkolona. Do tak dużej zmiany doszło z powodu wielu lat zaniedbań, jakich doświadczyło BOR. Cieniem na formacji położyła się również katastrofa smoleńska z 2010 r., która według byłego ministra obnażyła wiele nieprawidłowości w zakresie ochrony najważniejszej osoby w państwie. Ograniczeniom miały ulec również liczne przywileje funkcjonariuszy, które znacznie obciążały finansowo działanie formacji (Polskie Radio, 2017). W wywiadzie dla Polskiej Agencji Prasowej minister Błaszczak poinformował, że przyczyną wprowadzenia ustawy o Służbie Ochrony Państwa były wyniki niejawnego audytu przeprowadzonego w BOR pod koniec $2015 \mathrm{r}$. Zaznaczył również, że BOR było formacją zbyt małą i niedysponującą odpowiednimi środkami ochrony, aby zapewnić bezpieczeństwo najważniejszym osobom w państwie (PAP, 2018).

Zmianę pochwala również były szef Biura Ochrony Rządu w latach 2006-2007 i 2015-2017, gen. bryg. Andrzej Pawlikowski. Według niego gruntowna modyfikacja funkcjonowania służby odpowiedzialnej za ochronę VIP-ów w Polsce pozwoli na skuteczność i szybkość działań formacji. Według Pawlikowskiego, SOP jest również odpowiedzią na nowoczesne zagrożenia terrorystyczne dotyczące zarówno ochranianych osób, jak i obiektów. Były szef BOR zaznacza, iż nowe uprawnienia Komendanta SOP jako centralnego organu administracji, a także nowy zarząd operacyjno-rozpoznawczy znacząco przyczyni się do sprawności działania nowo powstałej formacji oraz wniesie wiele nowej jakości (W polityce, 2017). 
O potrzebie zmian informowali również sami funkcjonariusze. $\mathrm{W}$ przeprowadzonych badaniach ankietowych w zdecydowanej większości stwierdzili oni, że wykonując powierzone im zadania, nie mają wystarczającego oparcia $w$ istniejących regulacjach prawnych zawartych w ustawie o Biurze Ochrony Rządu oraz instrukcjach, zarządzeniach i rozporządzeniach wydanych przez Szefa BOR (Giełgut, 2018, s. 133-134).

Wielu funkcjonariuszy jako przyczynę likwidacji BOR wskazuje jednak głównie ograniczenie dotychczasowych przywilejów. Jednym $z$ najbardziej istotnych wydaje się ten wynikający z art. $83 \S 3$ Ustawy o Biurze Ochrony Rządu dotyczącego wysokości ekwiwalentu pieniężnego w zamian za rezygnację z przysługującego lokalu mieszkalnego. Według ustaw o BOR, wysokość wypłacanego ekwiwalentu na każdą osobę uprawnioną nie mogła być niższa niż 65\% i wyższa niż $80 \%$ wartości przysługującego lokalu, a stanowiła ona iloczyn maksymalnej należnej powierzchni mieszkaniowej przez wskaźnik 1,66 i cenę $1 \mathrm{~m}^{3}$. Cenę danego lokalu ustalało się według średnich cen rynkowych $\mathrm{w}$ zależności od miejsca pełnienia służby (Ustawa o Biurze Ochrony Rządu, 2001). Średnia wysokość wypłacanego ekwiwalentu wynosiła ponad 250 tys. złotych. Przy zmianie ustawy przywilej ten ograniczono praktycznie o połowę.

\section{RÓŻNICE USTAWOWE W DZIAŁALNOŚCI OBU FORMACJI}

Działania zarówno nieistniejącego już Biura Ochrony Rządu, jak i Służby Ochrony Państwa wynikają wprost z ustaw. Obydwie jednolite, umundurowane i uzbrojone formacje w założeniu miały wykonywać zadania z zakresu ochrony osób i obiektów. SOP dodatkowo ma za zadanie rozpoznawać oraz zapobiegać przestępstwom skierowanym przeciwko nim. Wiele ustawowych zadań obydwu formacji jest ze sobą tożsamych. Wyodrębnić można jednak kilka zasadniczych różnic, co przedstawiono w poniższej tabeli. 
Tabela 1

Porównanie ustawowych zadań Służby Ochrony Państwa i Biura Ochrony Rządu na podstawie Ustawy z dnia 16 marca 2001 r. o Biurze Ochrony Rzadu i Ustawy $z$ dnia 8 grudnia 2017 r. o Stużbie Ochrony Państwa

\begin{tabular}{|c|c|}
\hline Służba Ochrony Państwa & Biuro Ochrony Rządu \\
\hline \multicolumn{2}{|c|}{$\begin{array}{l}\text { "Ochrona Prezydenta Rzeczypospolitej Polskiej, Marszałka Sejmu, Marszałka Senatu, } \\
\text { Prezesa Rady Ministrów, wiceprezesa Rady Ministrów, ministra właściwego do } \\
\text { spraw wewnętrznych oraz ministra właściwego do spraw zagranicznych". }\end{array}$} \\
\hline \multicolumn{2}{|c|}{$\begin{array}{l}\text { "Ochrona byłych prezydentów Rzeczypospolitej Polskiej na podstawie ustawy z dnia } \\
30 \text { maja } 1996 \text { r. o uposażeniu byłego Prezydenta Rzeczypospolitej Polskiej (Dz. U. } \\
\text { z } 2017 \text { r. poz. 1992)". }\end{array}$} \\
\hline \multicolumn{2}{|c|}{ "Ochrona innych osób ze względu na dobro państwa". } \\
\hline $\begin{array}{l}\text { "Ochrona osób posiadających status } \\
\text { głowy państwa, szefa rządu oraz } \\
\text { ich zastępców, przewodniczącego } \\
\text { parlamentu lub izby parlamentu } \\
\text { lub ministra spraw zagranicznych, } \\
\text { wchodzących w skład delegacji państw } \\
\text { obcych przebywających na terytorium } \\
\text { Rzeczypospolitej Polskiej”. }\end{array}$ & $\begin{array}{l}\text { „Ochrona delegacji państw obcych } \\
\text { przebywających na terytorium } \\
\text { Rzeczypospolitej Polskiej”. }\end{array}$ \\
\hline $\begin{array}{l}\text { „Ochrona placówek zagranicznych } \\
\text { Rzeczypospolitej Polskiej wskazanych } \\
\text { w decyzji, o której mowa w art. } 4 \text { ust. } 8 \\
\text { Ustawy o Służbie Ochrony Państwa”. }\end{array}$ & $\begin{array}{l}\text { "Ochrona polskich przedstawicielstw } \\
\text { dyplomatycznych, urzędów } \\
\text { konsularnych oraz przedstawicielstw } \\
\text { przy organizacjach międzynarodowych } \\
\text { poza granicami Rzeczypospolitej } \\
\text { Polskiej". } \\
\end{array}$ \\
\hline $\begin{array}{l}\text { „Ochrona obiektów służących } \\
\text { Prezydentowi Rzeczypospolitej } \\
\text { Polskiej, Prezesowi Rady Ministrów, } \\
\text { ministrowi właściwemu do spraw } \\
\text { wewnętrznych oraz ministrowi } \\
\text { właściwemu do spraw zagranicznych } \\
\text { oraz wskazanych w decyzji ministra } \\
\text { właściwego do spraw wewnętrznych } \\
\text { innych obiektów stanowiących siedziby } \\
\text { członków Rady Ministrów, zwanych } \\
\text { dalej «siedzibami członków Rady } \\
\text { Ministrów», z wyłączeniem obiektów } \\
\text { służących Ministrowi Obrony Narodowej } \\
\text { i Ministrowi Sprawiedliwości". }\end{array}$ & $\begin{array}{l}\text { "Ochrona obiektów służących } \\
\text { Prezydentowi Rzeczypospolitej Polskiej, } \\
\text { Prezesowi Rady Ministrów, ministrowi } \\
\text { właściwemu do spraw wewnętrznych } \\
\text { oraz ministrowi właściwemu do spraw } \\
\text { zagranicznych". }\end{array}$ \\
\hline
\end{tabular}




\begin{tabular}{|l|l|}
\hline „Rozpoznawanie i zapobieganie & \\
przestępstwom przeciwko & \\
Rzeczypospolitej Polskiej, & \\
przestępstwom przeciwko życiu lub & \\
zdrowiu, przestępstwom przeciwko & \\
bezpieczeństwu powszechnemu, & \\
przestępstwom przeciwko & \\
bezpieczeństwu w komunikacji, & \\
przestępstwom przeciwko wolności, & \\
przestępstwom przeciwko czci & \\
i nietykalności cielesnej, przestępstwom & \\
przeciwko porządkowi publicznemu, & \\
zamachom i czynnej napaści & \\
skierowanym przeciwko osobom, & \\
o których mowa w pkt 1 lit. a-d, \\
oraz przeciwko bezpieczeństwu \\
obiektów, o których mowa w pkt 1 & \\
lit. e, z wyłączeniem dotyczących & \\
tych obiektów przestępstw przeciwko & \\
ochronie informacji”. & \\
\hline „Rozpoznawanie, zapobieganie & \\
i wykrywanie popełnianych przez & \\
funkcjonariuszy SOP, zwanych dalej & \\
«funkcjonariuszami», i pracowników & \\
SOP przestépstw korupcji, przekroczenia & \\
uprawnień oraz ujawniania & \\
tajemnicy zawodowej, służbowej oraz & \\
państwowej”. & \\
\hline „Prowadzenie rozpoznania pirotechniczno-radiologicznego obiektów Sejmu \\
i Senatu”.
\end{tabular}

Źródło: opracowanie własne na podstawie Ustawy z dnia 16 marca 2001 r. o Biurze Ochrony Rządu i Ustawy z dnia 8 grudnia 2017 r. o Służbie Ochrony Państwa.

Dzięki załączonej powyżej tabeli zauważyć można, że zadania zarówno starej, jak i nowej służby dbającej o bezpieczeństwo polskiego rządu nie zmieniły się diametralnie. Nadal głównym zadaniem obydwu formacji jest ochrona najważniejszych osób w państwie, na czele z Prezydentem RP i Prezesem Rady Ministrów. Formacją kierował będzie komendant, a nie jak to było dotychczas, szef BOR. Uzyskał on status centralnego organu administracji rządowej, co powinno usprawnić i przyspieszyć proces decyzyjny. W gestii komendanta SOP leżeć będzie dodatkowo określanie zakresu realizowanych działań ochronnych, czym dotąd zajmował się minister właściwy do spraw wewnętrznych. Nowa ustawa precyzuje dodatkowo krąg osób objętych ochroną w ramach delegacji dyplomatycznych. Minister 
właściwy do spraw wewnętrznych, ze względu na interes państwa, będzie mógł objąć ochroną również inne osoby niż te wymienione w katalogu (RCB, 2019).

Służba Ochrony Państwa, podobnie jak Biuro Ochrony Rządu, realizować będzie także zadania związane z ochroną obiektów. W ich skład oprócz ochranianych już wcześniej budynków służących Prezydentowi RP, premierowi, ministrowi właściwemu do spraw wewnętrznych oraz ministrowi właściwemu do spraw zagranicznych, wejdą również siedziby członków Rady Ministrów. Ochrona tych ostatnich podjęta zostanie jedynie na wniosek konkretnego członka gabinetu Rady Ministrów, przy zasięgnięciu opinii komendanta SOP i komendanta Policji. Ustawodawca nadał również uprawnienia do samodzielnego decydowania o ochronie obiektów Rady Ministrów ministrowi właściwemu do spraw wewnętrznych w trybie szczególnym.

Ustawodawca przy tworzeniu nowej formacji wyciągnął wiele wniosków z działalności jej poprzedniczki. Biorąc pod uwagę stan etatowy i zwiększenie nacisku na ochronę obiektów należących do członków Rady Ministrów, oczywiste okazało się zmniejszenie udziału SOP w ochronie placówek zagranicznych. Co do zasady, za ochronę takowych wedle znowelizowanych przepisów Ustawy o służbie zagranicznej odpowiada resort spraw zagranicznych, a dokładnie kierujący takową placówką (Ustawa o służbie zagranicznej, 2001). Za ochronę zarówno placówek zagranicznych, jak i personelu dyplomatycznego, w miejscach stacjonowania polskich kontyngentów wojskowych, odpowiedzialna będzie Żandarmeria Wojskowa (Ustawa o Żandarmerii Wojskowej, 2001). Biorąc pod uwagę ewentualność, że ochrona placówek zagranicznych przez Żandarmerię jest ograniczona jedynie do miejsca stacjonowania polskich kontyngentów wojskowych, premier, po analizie sił i środków, będzie mógł podjąć decyzję o objęciu ochrony placówki przez SOP. Z tego też powodu ustawodawca zastąpił określony katalog placówek, użyty w ustawie o BOR, definicją "placówki zagranicznej” zawartą w art. 4 Ustawy o służbie zagranicznej. Zgodnie z tym SOP może ochraniać placówki dyplomatyczne, urzędy konsularne, stałe przedstawicielstwa przy organizacjach międzynarodowych, instytuty polskie lub inne mające siedzibę poza terytorium RP placówki podległe ministrowi właściwemu do spraw zagranicznych (Ustawa o służbie zagranicznej, 2001). 
Jedną z najistotniejszych zmian przy porównaniu obydwu struktur jest możliwość prowadzenia przez funkcjonariuszy Służby Ochrony Państwa niejawnych czynności operacyjno-rozpoznawczych mających za zadanie zapobieganie przestępstwom przeciwko osobom ochranianym oraz obiektom (Ustawa, 2017). Według opinii Ministerstwa Spraw Wewnętrznych i Administracji zawartej w Ocenach Skutków Regulacji nadanie nowych uprawnień SOP ma wpłynąć na zwiększenie możliwości wykrywania i eliminowania potencjalnych zagrożeń. Uprawnienia operacyjno-rozpoznawcze istotnie wypłynąć mają również na skuteczność działań podczas całokształtu procesu ochronnego (MSWiA, 2017, s. 2-3). Dotychczas funkcjonariusze zapewniający bezpieczeństwo najważniejszym osobom w państwie w zakresie koniecznym do wykonywania zadań korzystać mogli z wiedzy uzyskiwanej przez inne służby, tj.: Policję, Agencję Bezpieczeństwa Wewnętrznego, Agencję Wywiadu, Służbę Kontrwywiadu Wojskowego, Straż Graniczna, Żandarmerię Wojskową (Ustawa o Biurze Ochrony Rządu, 2001). Zasługują na odnotowanie wyraźne różnice pomiędzy statutowymi zadaniami wymienionych formacji. Informacje pozyskiwane w toku niejawnych czynności operacyjno-rozpoznawczych przez organy ścigania, jak i służby specjalne były niejednokrotnie zbyt mało szczegółowe w zakresie ochrony osób. Kolejny problem rodziła jakość i szybkość przepływu informacji między poszczególnymi służbami. Długotrwałe procesy pozyskiwania danych istotnie rzutowały na efektywność realizowanych zadań przez Biuro Ochrony Rządu. Powierzenie tak istotnych uprawnień kolejnej formacji dbającej o bezpieczeństwo w Polsce było nieuniknionym krokiem do przodu w budowie skutecznych i prężnie działających służb ochronnych. W skali świata Polska nie jest pionierem takich rozwiązań, a jedynie powiela sprawdzone wcześniej wzorce. Uprawnienia do niejawnych czynności operacyjno-rozpoznawczych posiadają chociażby U.S. Secret Service (Secret Service, 2019) czy Federalna Służba Ochrony Federacji Rosyjskiej (FSO, 2019). 


\section{BADANIA WŁASNE}

Przedmiot podjętej pracy badawczej stanowili byli funkcjonariusze Biura Ochrony Rządu, którzy na mocy ustawy z dnia 8 grudnia 2017 r. weszli w struktury nowo powstałej Służby Ochrony Państwa. Głównym celem przeprowadzenia badań było poznanie opinii na temat zmian, które nastały po przekształceniu obydwu formacji mundurowych. Poznanie opinii funkcjonariuszy różnego szczebla jest elementem niezbędnym do zrozumienia tematyki omawianego problemu. Próbę przeprowadzono na grupie 50 osób w 2018 r. Do uzyskania wyników użyto metody sondażu diagnostycznego z uwagi na pełną anonimowość i łatwość dostępu. Kwestionariusz zawierał pytania o charakterze zamkniętym oraz półotwartym.

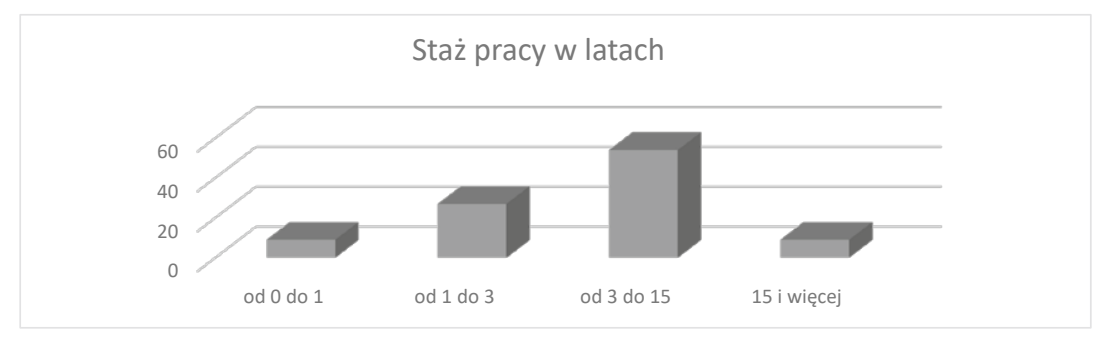

Wykres 1. Staż w latach.

Źródło: opracowanie własne.

Pierwsze pytanie zawarte $\mathrm{w}$ ankiecie dotyczyło stażu służby określonego w latach. Zdecydowana większość respondentów (54,5\%) posiada od 3 do 15 lat stażu służby. Na drugim miejscu (27\%) znajdują się osoby, które ukończyły pełen rok służby, ale przebywają nadal w służbie kandydackiej z uwagi na wysługę nieprzekraczającą 3 lat. Dwiema najmniejszymi grupami (9\%) są nowo przyjęci funkcjonariusze oraz ci najbardziej doświadczeni powyżej 15 lat służby. 


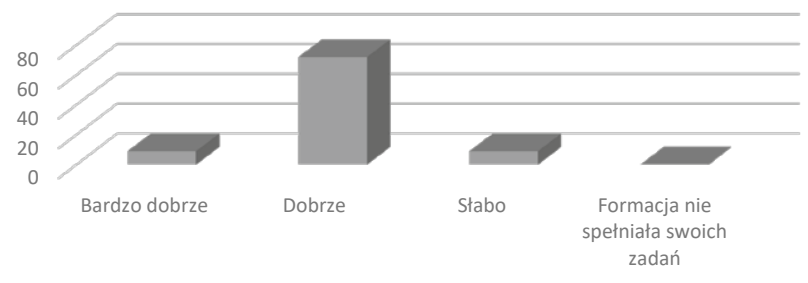

Wykres 2. Ocena realizacji ustawowych zadań przez BOR.

Źródło: opracowanie własne.

Drugie pytanie zadane $\mathrm{w}$ ankiecie dotyczyło oceny realizacji ustawowych zadań przez Biuro Ochrony Rządu. Ponad 72,5\% funkcjonariuszy dobrze ocenia pracę byłej jednostki strzegącej bezpieczeństwa najważniejszych osób w państwie. Warty odnotowania jest fakt, iż nikt z grupy 50 osób nie stwierdził rażącego niewypełniania swoich zadań przez BOR. Grupa osób, które oceniły poprzedniczkę Służby Ochrony Państwa w sposób bardzo dobry oraz słaby, uplasowała się na poziomie $9 \%$.

\section{W jakim stopniu ustawa o SOP spełnia Pani/Pana oczekiwania?}

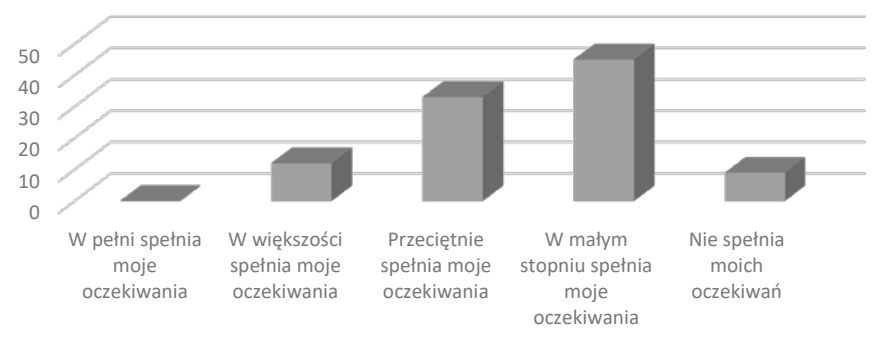

Wykres 3. Stopień spełnienia oczekiwań przez nową ustawę.

Źródło: opracowanie własne.

W kolejnej części ankiety zadano pytanie odnośnie do stopnia usatysfakcjonowania funkcjonariuszy nową ustawą o Służbie Ochrony Państwa. Z powyższego wykresu wywnioskować można, że nie 
przyniosła ona oczekiwanych zmian. Nikt spośród grona 50 osób nie stwierdził, że nowa ustawa w pełni spełnia jego oczekiwania. Tylko grupa 12\% respondentów zaznaczyła, iż w większości jest usatysfakcjonowana nowymi rozwiązaniami. Prawie połowa, bo aż $45 \%$, jest zdania, że ustawa o Służbie Ochrony Państwa tylko w niewielkim stopniu spełnia pokładane $\mathrm{w}$ niej nadzieje. Jedna trzecia (33\%) funkcjonariuszy ocenia zmiany legislacyjne przeciętnie w stosunku do ich oczekiwań. Z kolei 9\% respondentów jest całkowicie nieusatysfakcjonowanych ustawą o Służbie Ochrony Państwa.

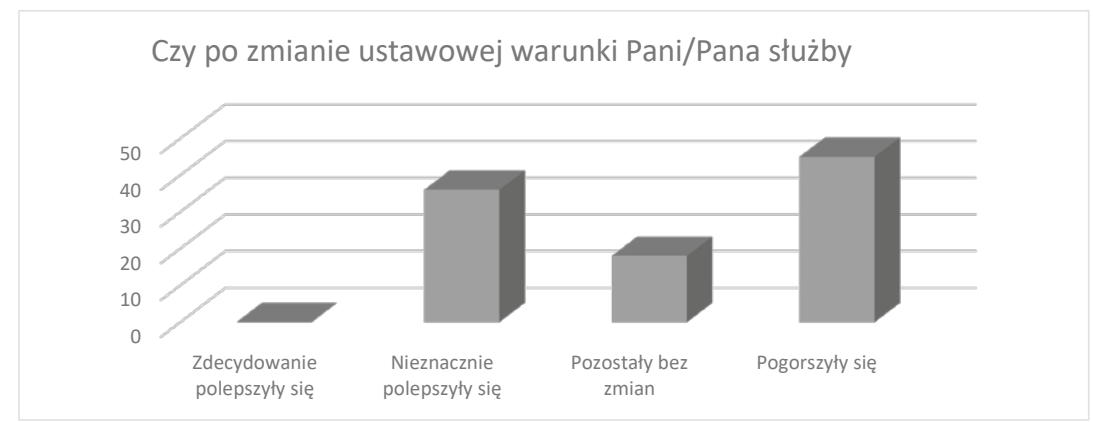

Wykres 4. Ocena zmian warunków służby.

Źródło: opracowanie własne.

Jednymi z najistotniejszych pytań, jakie zadano grupie respondentów, były te dotyczące warunków ich służby po zmianie omawianych formacji. Kolejny raz nikt spośród grona 50 osób nie opowiedział się w sposób stanowczy za zdecydowanymi zmianami na lepsze. Nieznaczną pozytywną różnicę zauważyło $36 \%$ respondentów, jednak większość od powiadających na pytanie stwierdziła, że warunki służby pogorszyły się w porównaniu do tych z okresu BOR. 


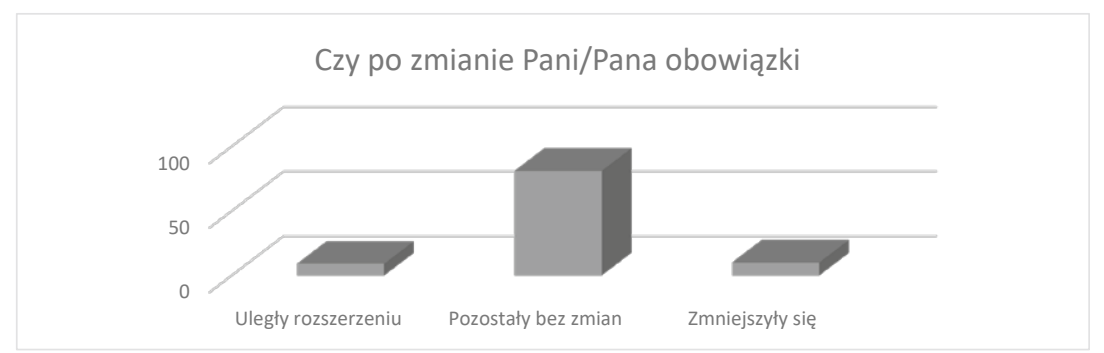

Wykres 5. Ocena zmiany obowiązków

Źródło: opracowanie własne.

Zdecydowana większość funkcjonariuszy zapytana o zakres obowiązków przed i po zmianie ustawy odpowiedziała, że te pozostały bez zmian (81\%). Rozszerzenie powinności służbowych odnotowało $9 \%$ respondentów. 10\% funkcjonariuszy odpowiedziało, że ich obowiązki zmniejszyły się w porównaniu do tych za czasów funkcjonowania Biura Ochrony Rządu. Wyniki te ukazują jak niewielka liczba osób służących w obydwu formacjach zauważyła istotne zmiany spowodowane powołaniem do istnienia Służby Ochrony Państwa.

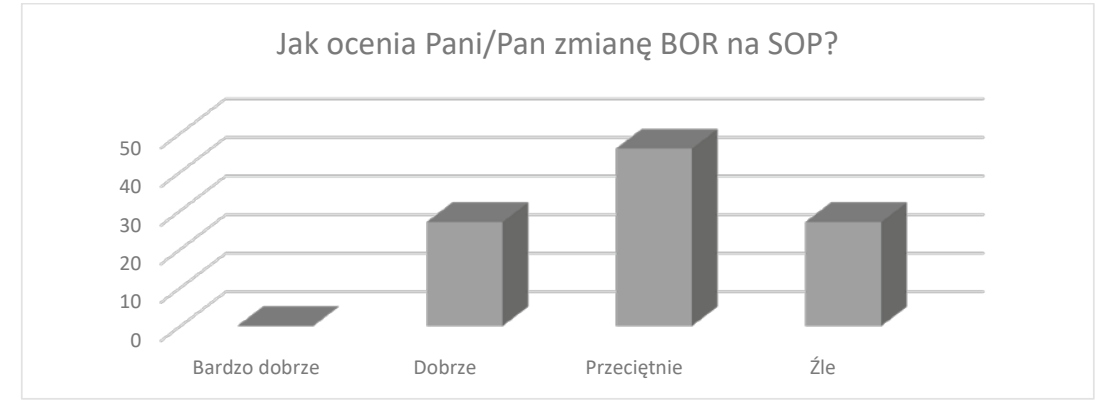

Wykres 6. Ocena zmiany BOR na SOP.

Źródło: opracowanie własne.

Ostatnim pytaniem, jakie zadano ankietowanej grupie funkcjonariuszy, była ocena ogólna zamknięcia Biura Ochrony Rządu i utworzenia w jego miejsce Służby Ochrony Państwa. Powyższy wykres w sposób wymowny pokazuje, że zamknięcie Biura Ochrony Rządu zdaniem ankietowanych nie było najlepszym rozwiązaniem. Blisko połowa (46\%) oceniła efekty zmiany w sposób przeciętny, natomiast 
równo $27 \%$ ankietowanych funkcjonariuszy uznało ten proces za dobry, a pozostali za skrajnie zły. Fakt ten może być związany z niedługim okresem działania Służby Ochrony Państwa, a co za tym idzie lękiem przed tym, co świeże i nowe. $Z$ drugiej strony może był to rezultat złych rozwiązań prawnych, które mając ułatwić służbę w SOP, przyniosły odmienny efekt. Dzięki temu pytaniu zauważyć można zarówno wiele oczekiwań, jak i niespełnionych nadziei.

\section{PODSUMOWANIE}

Służba Ochrony Państwa powołana do życia 1 lutego 2018 r. w miejsce dawnego Biura Ochrony Rządu jest formacją nowa, a ocenić ją będziemy mogli dopiero z perspektywy kilku następnych lat. Już teraz jednak powiedzieć można jasno, iż formacja zapewniająca bezpieczeństwo najważniejszym osobom $\mathrm{w}$ państwie musiała przejść zdecydowaną reformę. Duże zaniedbania zarówno pod względem finansowym, kadrowym, jak i ustawowym, rodziły wiele zagrożeń dla prawidłowości wykonywania tak istotnych zadań z punktu widzenia polskiej racji stanu. Zagrożenia te widział już gen. bryg. Andrzej Pawlikowski, który jasno i wyraźnie stwierdził, iż Biuro Ochrony Rządu nie było już w stanie w pełni wypełniać powierzonych mu zadań ochronnych członków Rady Ministrów i Prezydenta RP. Autor artykułu podaje jednak w wątpliwość powołanie całkowicie nowej służby, jaką stała się SOP. Usprawnienie funkcjonowania służby ochronnej polskiego rządu mogło się odbyć na zasadzie reformy ustawy o BOR. Wdrożenie nowych uprawnień, zadań oraz zmian strukturalnych nie wymagało tworzenia całkowicie nowej służby. Tak długo zapowiadana reforma formacji przyniosła falę odejścia doświadczonych funkcjonariuszy niepewnych jutra. Dostali oni ofertę przejścia do SOP bez pewności utrzymania uposażeń i dodatków na tym samym poziomie. Rzesza z nich posiadająca już uprawnienia emerytalne w obliczu niewiadomego wolała odejść na rynek prywatny. Funkcjonariusze BOR w momencie wejścia w życie nowej ustawy stali się automatycznie funkcjonariuszami SOP. Jednocześnie, aby nadal nieprzerwanie służyć w nowej formacji, musieli oni uzyskać od Komendanta SOP pisemną propozycję określającą nowe warunki pełnienia służby. Jeżeli funkcjonariusz w określonym 
terminie takowej propozycji nie otrzymał, bądź otrzymał pisemną informację o braku takiej propozycji, to jego stosunek służbowy wygasał. Przy przedstawianiu propozycji Komendant SOP brać miał pod uwage przydatność w nowo powstałej formacji oraz przebieg służby BOR. Warunki te stwarzały możliwość dowolnego rotowania kadrami, opierając się na ściśle subiektywnych opiniach kadry kierowniczej (Ura, 2019). Zmiany na polu kadrowym doprowadziły już na początku działalności SOP w 2018 r. do kryzysu, formacja zanotowała rekordowy odsetek wakatów na poziomie 17,6\%, co daje prawie 418 etatów (Lesiecki, 2018). Jednym z głównych zarzutów kierowanych w stronę funkcjonariuszy BOR z sejmowej mównicy była ich niekompetencja oraz brak odpowiedniego przeszkolenia, jednakże proces naboru oraz adaptacji przyszłych funkcjonariuszy do służby w SOP wygląda niemal identycznie jak w BOR (Matysek, 2017). Likwidacja BOR wiązała się również z olbrzymimi nakładami finansowanymi związanymi ze zmianami na polu logistycznym. Wiele przetargów i konkursów związanych z całkowitą zmianą formacji strzegącej bezpieczeństwa polskiego rządu kosztowało podatnika dodatkowe miliony złotych.

Przeprowadzone na potrzeby artykułu badania wykazały jasno, iż sami funkcjonariusze nie widzą wielu pozytywów przejścia do SOP. Niepewność związana z dużą ilością zmian, fala odejść doświadczonych funkcjonariuszy, którzy de facto powinni wdrażać młodych adeptów w realia służby, niezwykle negatywny oddźwięk medialny nowej formacji oraz brak zmian na gruncie szkoleniowym to tylko niektóre elementy przyczyniające się do negatywnego postrzegania nowych realiów ochrony najważniejszych osób w Polsce pod sztandarem Służby Ochrony Państwa.

\section{Bibliografia}

Federalna Służba Ochrony. (2019). O tworzeniu Federalnej Stużby Ochrony w Rosji. Pozyskano z: http://fso.gov.ru/history/ob_istorii_sozdaniya/ (dostęp: 03.12.2019).

Giełgut, M. (2018). Funkcjonowanie Służby Ochrony Państwa a konstytucyjne prawa i wolności jednostki. Przeglad Prawa Konstytucyjnego, 3(43), 133-134. 
Lesiecki, R. (2018). Wakaty w stużbach: po kilkanaście procent w SOP i SG, po kilka w policji i PSP. Pozyskano z: https://www.infosecurity24.pl/ wakaty-w-sluzbach-po-kilkanascie-procent-w-sop-i-sg-po-kilka-w-policji-i-psp (dostęp: 12.12.2019).

Matysek, K. (2017). Adaptacja zawodowa funkcjonariusza w służbie mundurowej na przykładzie Biura Ochrony Rządu. Security, Economy $\mathcal{E}$ Law, 3/2017, 133-136.

Ministerstwo Spraw Wewnętrznych i Administracji. (2017). Ocena Skutków Regulacji projektu o Państwowej Stużbie Ochrony. Pozyskano z: https://archiwumbip.mswia.gov.pl/download /4/34867/OSR.pdf (dostęp: 12.02.2019).

Najwyższa Izba Kontroli. (2005). Informacja o wynikach kontroli realizacji zadań ustawowych przez Biuro Ochrony Rządu. Warszawa: Najwyższa Izba Kontroli numer kontroli: P/05/083.

Polska Agencja Prasowa. (2017). Szef MSWiA: zmiana BOR w SOP konieczna; opozycja krytyczna. Pozyskano z: https://www.pap.pl/aktualnosci/ news\%2C1159164\%2Cszef-mswia-zmiana-bor-w-sop-konieczna\%3B-opozycja-krytyczna-.html (dostęp: 12.02.2019). Polskie Radio. (2017). Mariusz Błaszczak: nie będzie dymisji szefa Biura Ochrony Rządu. Pozyskano z: https://www.polskieradio.pl/7/129/Artykul/1727430,Mariusz-Blaszczak-nie-bedzie-dymisji-szefa-Biura-Ochrony-Rzadu (dostęp: 12.02.2019).

Rządowe Centrum Bezpieczeństwa. (2019). Służba Ochrony Państwa a Biuro Ochrony Rzadu - redefinicja zadań i uprawnień. Pozyskano z: http:// rcb.gov.pl/sluzba-ochrony-panstwa-a-biuro-ochrony-rzadu-redefinicja-zadan-i-uprawnien (dostęp: 05.11.2019).

Secret Service. (2019). The investigative mission. Pozyskano z: https://www. secretservice.gov/investigation/ (dostęp: 03.12.2019).

Służba Ochrony Państwa. (2019). Historia. Pozyskano z: https://www. sop.gov.pl/pl/o-sluzbie/historia/historia-sop/201,Historia.html (dostęp: 07.02.2019).

Ura, E. (2019). Likwidacja Biura Ochrony Rządu, utworzenie Służby Ochrony Państwa. Acta Universitatis Lodziensis Folia Iuridica, 87(2019), 126-127.Ustawa z dnia 16 marca 2001 r. o Biurze Ochrony Rządu (Dz. U. 2001 nr 27 poz. 298).

Ustawa z dnia 27 lipca 2001 r. o służbie zagranicznej (Dz. U. 2001 nr 128 poz. 1403).

Ustawa z dnia 24 sierpnia 2001 r. o Żandarmerii Wojskowej i wojskowych organach porządkowych (Dz. U. z 2016 r. poz. 1483 i 1948 oraz z 2017 r. poz. 244, 768 i 1086).

Ustawa z dnia 8 grudnia 2017 r. o Służbie Ochrony Państwa (Dz. U. 2018 poz. 138). 
Zespół wPolityce.pl. (2017). Gen. Pawlikowski: Przekształcenie BOR w SOP, która zyska nowe uprawnienia, to rozwiazanie wzmacniajace system bezpieczeństwa państwa. Pozyskano z: https://wpolityce. $\mathrm{pl} /$ polityka/372746-gen-pawlikowski-przeksztalcenie-bor-w-sop-ktora-zyska-nowe-uprawnienia-to-rozwiazanie-wzmacniajace-system-bezpieczenstwa-panstwa (dostęp: 12.02.2019).

\section{Copyright and License}

This article is published under the terms of the Creative Commons Attribution - NoDerivs (CC BY- ND 4.0) License http://creativecommons.org/licenses/by-nd/4.0/ 